\title{
5 .ブランケット工学の最前線
}

\author{
西川正史, 深田智, 清水昭比古, 井口哲 夫 ${ }^{11}$ \\ (九州大学大学院, ${ }^{1)}$ 名古屋大学大学院)
}

\section{T he Frontier s of Research on F usion Blanket T echnology}

\author{
NISHIKA WA Masabumi, FUKA DA Satoshi, SHIMIZU A kihiko and IGUCHI T etsuo ${ }^{1)}$ \\ Kyushu University, Fukuoka, 812-8581 Japan \\ 1)Nagoya University, Nagoya, 464-8602 Japan
}

(Received 2 A pril 2003)

\begin{abstract}
Current topics concerning blanket technology are review ed. In the chemical engineering/chemistry ar ea, the qualitative and quantitative effects of mass transfer steps of tritium is important in the understanding of the behavior of bred tritium in the solid breeder blanket sy stem. Such phenomena as adsor ption, isotope exchange reactions, and $w$ ater formation reaction at the grain surface produce profound effects on the behavior of the bred tritium in the blanket. Regarding the liquid sy stem, the phy sical or chemical properties of Li, $\mathrm{Li}_{17} \mathrm{~Pb} 83$ and $\mathrm{F}$ libe as liquid blanket materials were compared. Some recent studies w ere introduced regarding tritium recovery from the liquid blanket materials, impurity removal from salts, cer amic coating of structural materials, and the vapor pressure of mixtures of metals or salts. T hermal hy draulic topics in relation to several candidate power reactor concepts are summarized. Emphasis is laid on the simultaneous removal of heat and tritium from the blanket and some aspects of forming effective pow er cy cles are dev eloped.
\end{abstract}

Keywords:

lithium cer amic, tritium, tr ansfer, adsor ption, diffusion, isotope exchange, liquid lithium, LiPb, F libe, ceramic coating, vapor pressure, thermal hydraulic power cycle

\section{1 化学・化学工学 (固体系)}

511 固体ブランケットにおけるトリチウムの移行挙動 核融合炉のブランケットでは燃料の増殖と熱発生が行 われるので事実上の炉心と見なされるところであるが， トリチウムの自己補給性を確保するとともに環境への卜 リチウムの漏洩を評価して放射線安全性を高めるために も , ブランケットにおけるトリチウムの挙動の把握が必 要である . 現在核融合炉のトリチウム増殖材としては， $\mathrm{Li}_{2} \mathrm{O}, \mathrm{LiA} \mathrm{IO}_{2}, \mathrm{Li}_{2} \mathrm{ZrO}_{3}, \mathrm{Li}_{2} \mathrm{~T} \mathrm{iO}_{3}, \mathrm{Li}_{4} \mathrm{SiO}_{4}$ 等の固体増殖 材の使用が有力視されている.これまで固体ブランケッ author'se-mail: nishikaw@nucl.kyushu-u.ac.jp
トからのトリチウム放出特性を把握することを目的とし て世界中で多くのin-situ または照射後トリチウム放出実 験が行われてきたが, 各研究相互の不一致が大きく, 増 殖トリチウムの挙動の解析は頓挫状態のままブランケッ 卜設計が進められている.

直径 $1 \mathrm{~mm}$ 程度の大きさに焼結された多孔質固体増殖 材粒子を構成する $1 \mu \mathrm{m}$ 程度の結晶グレインの中に Li 中性子反応で作られたトリチウムがブランケットパージ ガス気流へ移行・放出されるまでに関与する物質移動過 程として筆者は以下のような現象を考えている[1-5] . 
1 ) トリチウムの生成反応

2 ) 固体増殖材結晶グレイン内の拡散

3 ) 照射欠陥とトリチウムの相互作用という結晶グレ イン内の物質移動過程と，

4 ) グレイン表面でのトリチウム水蒸気の吸着・脱着

5 ) グレインバルクへのトリチウムの吸収

6 ) グレイン表面のトリチウムと気流中の水素との同 位体交換反応 (同位体交換反応 1 )

7 ) グレイン表面のトリチウムと気流中の水蒸気との 同位体交換反応 (同位体交換反応 2 )

8 ) パージガスに水素を添加したことによって起こる ブランケット材からの水分発生反応

9 ) 水素, 水蒸気による増殖材グレイン表面性状の変 化

10）Liの質量移行という結晶グレイン表面における物 質移行過程および

11) 水素同位体および水蒸気のブランケット焼結体の 細孔内拡散

12）水素同位体および水蒸気のブランケット焼結体の 外部境膜内拡散

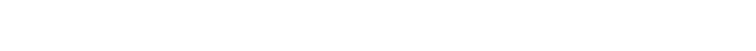
分圧, 水蒸気分圧, 粒子形等の影響は異なるので, 固体 ブランケットにおけるトリチウムの挙動を把握するため には，各移動過程の特性を定量的に知らなければならな い . 筆者のこれまでの実験で得られた上記表面現象と温 度の対応関係を乾燥ガスパージ，水素パージおよび水蒸 気パージの場合について T able1に比較をした .

なお，トリチウムの挙動に関する特性値を実験的に求

Table 1 Tritium transfer phenomena on the solid breeding materials and correlation with purge gas.

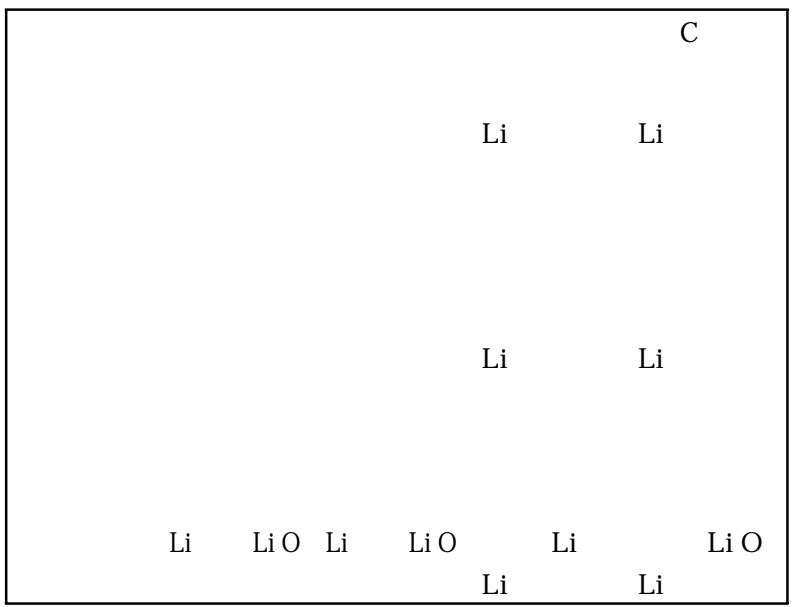

める際に留意しておかねばならないことは, トリチウム と装置配管との相互作用によって引き起こされるトリチ ウムのシステム効果 ，モニター電極表面とトリチウムの 相互作用によって引き起こされるメモリ効果 [6]，およ びパージガス成分によって電離箱出力が変化するジェス 効果への定量的理解である .

512 ブランケット中のトリチウムインベントリの推定

筆者らは固体ブランケット中に捕捉されるトリチウム は主として，(1)グレイン内拡散過程にあるトリチウム (関与現象上記分類の1～3 ), (2)グレイン内に吸収され たトリチウム(関与現象 5 と8)，(3)グレイン表面に吸着 状態にあるトリチウム(関与現象 4 と 8 )，および表面構 造水等同位体交換可能官能基に取り込まれているトリチ ウム (関与現象 6〜8) の4種類に大別されると考え定 量式を作成した $[4,5]$.この結果，過去不一致であった 種々のin-situ実験で報告された各種ブランケット材にお けるトリチウムインベントリをまとめることができた . トリチウムの有効拡散係数は一連のEXOTIC 実験の拡 散律速と思われる報告值から求めた值または工藤と奥野 によって報告された值を用いたが， $500 \mathrm{~K}$ 以上の温度で は $\mathrm{LiA} \mathrm{IO}{ }_{2}$ 以外では拡散係数インベントリの占める割合 は無視できる程度であった . $1 \mathrm{GW}$ 発電の実用炉を想定 して $\mathrm{Li}_{2} \mathrm{ZrO}_{3}$ 増殖材を使ったブランケットにおけるトリ チウム滞留時間を比較したところ[4], グレインサイズが $1 \mu \mathrm{m}$ 以下では $573 \mathrm{~K}$ 以上の温度域で表面インベントリが 支配的である．またグレインサイズが $10 \mu \mathrm{m}$ でも，拡散 の影響か強くなるのは $773 \mathrm{~K}$ より低い温度である．また 表面，拡散どちらのインベントリも支配的ではない領域 も存在する . ブランケットの設計に際しては乥れ光れの 領域で現象に強く影響を与える因子は異なることに留意 が必要である．また，完全混合の仮定が成立しないブラ ンケットにおけるトリチウムの挙動把握が次の課題であ る。

513 トリチウム放出曲線のシミュレーション

定常状態のインベントリの場合とは異なり，ブラン ケットの操作条件か変化した際にえられるトリチウム放 出曲線のような動的挙動は, グレイン表面における諸反 応とともにグレイン内の拡散係数の影響も強く受ける . 筆者らが $\mathrm{Li}_{4} \mathrm{SiO}_{4}$ について照射後放出実験を行った際水 素と水蒸気および乾燥ガスをパージガスに用いた場合に 得られた放出曲線を Fig.1に示す . パージガスとして水 蒸気を用いたほうが速やかなトリチウム放出が認められ ているのに対して，水素を用いた場合の放出曲線では卜 リチウムの放出の始まりが遅くかつ緩やかになってい 


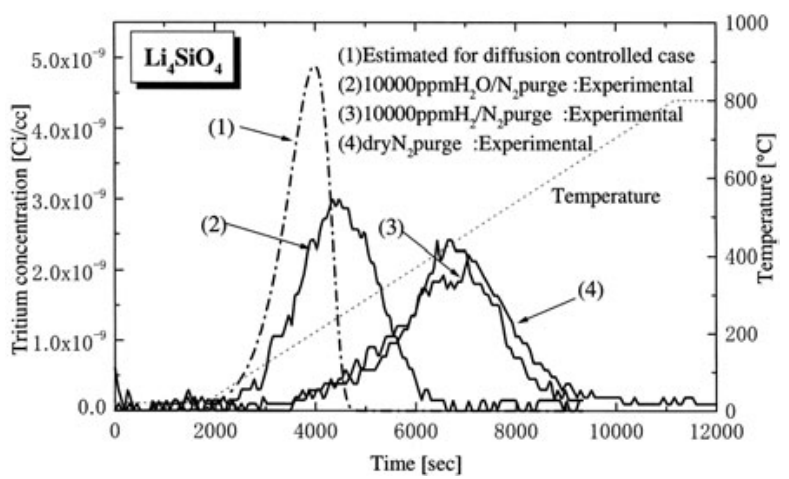

Fig. 1 Tritium release curve from $\mathrm{Li}_{4} \mathrm{SiO}_{4}$ made by FZK. Irradiated at Kyoto University Research Reactor.

る .この比較は水素パージ条件で拡散係数を求めること は大きな誤差を生みうることを示しているので，筆者ら はより拡散律速に近い水蒸気パージによる放出曲線に表 面反応の効果を加味した解析から拡散係数を求めること を推奨する . また水素パージと乾燥ガスパージに差が光 れほど見られない．この原因は水蒸気を相手にした同位 体交換反応 2 は室温でも速やかであるのに対して，水素 を相手にした同位体交換反応 1 は 700 800 K を超える 高温にならないかぎり極遅いためである[3] . また Li ${ }_{2}$ $\mathrm{TiO}_{3}$ は水素雾囲気で高温場に置かれるとグレイン表面 で還元反応が起こり水を発生する.この表面の性状変化 に伴い $\mathrm{Li}_{2} \mathrm{~T} \mathrm{iO}_{3}$ 表面では同位体交換反応 1 が極端に低下 することも認めている[7-10] . これらの測定結果は水素 パージ $\mathrm{Li}_{2} \mathrm{~T} \mathrm{iO}_{3}$ ブランケットでは低温でも高温でも放出 トリチウムにはHTO または $\mathrm{T}{ }_{2} \mathrm{O}$ の化学形が多く含まれ ることを示しており，このことは筆者らの照射後放出実 験でも確認されている .

照射量によってトリチウムの有効拡散係数も変化する ようである[11] .

増殖トリチウムの効率的回収方法の開発と発電系への トリチウム漏洩低減化対策を講ずるためには固体増殖材 からのトリチウムの放出挙動の定性的かつ定量的把握と 弚れに基づく解析法の確立が必要であるか現状はまだま だ不十分な段階にある。

(西川正史)

\section{2 化学・化学工学 (液体系)}

\section{1 液体ブランケット材の特徵}

液体ブランケットは, メインテナンスが容易, 配管系 を含めた構造が簡単, トリチウム増殖率が大きい等の特 徵がある一方, 共存性のある材料が限られ，MHD 効果 によりポンプ動力が大きくなる可能性があり，液体金属
Table 2 Hydrogen solubility, diffusivity and major constants of Liquid $\mathrm{Li}_{1} \mathrm{Li}_{17} \mathrm{~Pb}_{83}, \mathrm{Li}_{2} \mathrm{BeF}_{4}$.

\begin{tabular}{|l|l|l|l|}
\hline & $\mathrm{Li}$ & $\mathrm{Li}_{17} \mathrm{~Pb}_{83}$ 共融合金 & $\begin{array}{l}\mathrm{Li}_{2} \mathrm{BeF}_{4} \text { ( Flibe ) } \\
\text { 溶融塩 }\end{array}$ \\
\hline 融点 /沸点 & $179^{\circ} \mathrm{C} / 1372^{\circ} \mathrm{C}$ & $235^{\circ} \mathrm{C} / 1300^{\circ} \mathrm{C}$ 以上 & $458^{\circ} \mathrm{C} / 1300^{\circ} \mathrm{C}$ 以上 \\
\hline $\begin{array}{l}10^{5} \mathrm{~Pa} / 1 \mathrm{~Pa} \\
\text { 水素平衡溶 } \\
\text { 解度 }\end{array}$ & $\begin{array}{l}\mathrm{LiH}(\mathrm{solid}) / \\
5.9 \times 10^{-3}\end{array}$ & $6.1 \times 10^{-6} / 1.9 \times 10^{-8} 8$ & $\begin{array}{l}4.4 \times 10^{-8}(\mathrm{wt} . \mathrm{fr}) / \\
4.4 \times 10^{-13}(\mathrm{wt} . \mathrm{fr})\end{array}$ \\
\hline 水素拡散係数 & $3.2 \times 10^{-10 \mathrm{~m}^{2} / \mathrm{s}}$ & $2.7 \times 10^{-9} \mathrm{~m}^{2} / \mathrm{s}^{*}$ & $1.3 \times 10^{-11} \mathrm{~m}^{2} / \mathrm{s}^{*}$ \\
\hline 粘度 & $3.1 \times 10^{-3} \mathrm{Poise}$ & $\left(2.0 \times 10^{-2} \mathrm{Poise}\right)$ & $8.5 \times 10^{-2} \mathrm{Poise}$ \\
\hline 電気伝導度 & $2.7 \times 10^{4}(\Omega \mathrm{cm})^{-1}$ & $\left(1.1 \times 10^{4}(\Omega \mathrm{cm})^{-1}\right)$ & $2.2(\Omega \mathrm{cm})^{-1}$ \\
\hline 蒸気圧 & $12 \mathrm{~Pa}$ & $(2.1 \mathrm{~Pa})$ & $0.24 \mathrm{~Pa}$ \\
\hline 熱伝導率 & $56 \mathrm{~W} / \mathrm{mK}$ & $(23 \mathrm{~W} / \mathrm{mK})$ & $0.93 \mathrm{~W} / \mathrm{mK}$ \\
\hline
\end{tabular}

あるいは溶融塩を取り扱うにたる十分な技術か習熟して いない等の欠点がある . 潜在的優位性のため常に研究者 の興味の的になっているが，研究の進捗具合から言え ば，固体ブランケットに比べてはるかに遅れている.特 に中性子照射下の高温耐食性の問題から液体ブランケッ 卜構造材に果たされた条件が厳しく，許された設計ウィ ンドが限られてくる.1980年代までは核融合炉ブラン ケットとしての研究が主であったが, 最近は強力中性子 フラックスによる損傷を緩和するための液体膜としての 研究も多い.

代表的な液体ブランケット材料の $L i ， L_{1} i_{1} P_{83}$ 共融合 金, Flibe 溶融塩の融点, 水素溶解度, 水素拡散係数, 光 の他いくつかの物性値を T able 2 に比較する .すべて

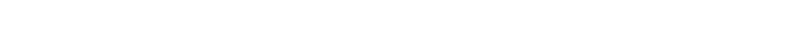
験データが見当たらず，Li と Pb のモル混合比を使って 推算した . また*を付けた值は実験值であるが，他に比 べて精度が保証できない，水素とトリチウム間の同位体 効果は, $\mathrm{Li}-$ 水素系の溶解度曲線のみ求められており，

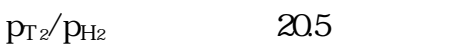

Li はトリチウム増殖性能が最も良く，また粘度が小さ く熱伝導率が大きいので泠却材としても優れている．し かし電気伝導度が非常に大きく $\mathrm{Na}$ ほどではないが,酸 素, 室素と反応するので磁場および空気からシールドす る必要がある.Pb あるいは Be は中性子増倍材として機 能するのと, 状態図上の優位性から $\mathrm{Li}_{1} 7 \mathrm{~Pb}_{83}$ と $\mathrm{Li}_{2} \mathrm{BeF}_{4}$ [12]が中心的に研究されてきた . また F の中性子吸収断 面積が $9.6 \mathrm{mb}$ と小さいので, Li , Li - Pb では中性子増倍 材なし，Flibeでは適当な増倍材を加えることでトリチ ウム増殖率を 1 以上にできる[13] .

Flibe $\mathrm{LiF}$ と BeF ${ }_{2}$ の $2: 1$ 比の混合溶融塩であり, 粘 度はBeの割合とともに増加し, 純BeF ${ }_{2}$ はガラスス状でLiF の約 $10^{6}$ 倍にもなる．したがって中性子照射によって物 
性値の変化が生じる可能性がある . フッ化物は安定であ るが, トリチウムは TF としても存在し, 構造材の酸化 腐食を起こすので光れほど高温にはできない．Flibe の 設計ウインドを下げる一つの方法として Flinabe( LiF+ $\mathrm{NaF}+\mathrm{BeF}_{2}$ )があるが , データがいまだ少なくさらに検 討が必要であろう。

労働環境衛生法によれば Be の作業環境濃度を $2 \mu \mathrm{g} /$ $\mathrm{m}^{3}$ 以下にする必要があり, 取り扱いが極めて厳しい.Be の毒性も化学形態によって変わると考えられることか ら, 今後トリチウムとともに Be の安全性研究をさらに すすめる必要性がある。

522 最近の研究から

Li/N 合金あるいは Li/フェライト鋼系のブランケット では, 構造材表面のセラミックコーティング (例えば $\mathrm{A} I \mathrm{~N}, \mathrm{Y}_{2} \mathrm{O}_{3}, \mathrm{Er}_{2} \mathrm{O}_{3}$ 等) の耐食性が研究されている [14]. 現在は, 静置した材料の腐食挙動を調べているが, 今後 は流れ系の研究に向かうだろう.Flibe は ORNL の溶融 塩実験炉以後, 核融合関係の実験的研究はほぼ日本でな されてきたが, Flibe 中のトリチウムの溶解度は非常に 小さく，また产の化学的存在形は,Flibe の酸化還元状態 によって $\mathrm{T}_{2}(\mathrm{HT})$ 加 $\mathrm{T}$ のいずれかをとると考えられ，特 に日米研究協力 JUPIT ER- II で(1)F libe 中の不純物制御， (2)Flibe/構造材系からのトリチウム透過漏洩の評価， (3)F libe の安全性の観点から空気や水蒸気との反応性, 高温におけるFlibeの蒸発挙動が調べられている [15,16]. 特に不純物除去に関する最近の成果として， $\mathrm{HF} / \mathrm{H}_{2}$ ガスバブリングにより炭素と酸素が除去され,さ らにBeの添加による金属不純物の除去の可能性が検討 されている .

液体 Li の蒸気圧はかなり高く，弚れを液体膜で使用す るのに，蒸発量を押さえるためLi - Sn 共融合金が考えら れている.Snは融点が低いのに蒸気圧は乥れほど高くな い . 例えば , Sn- 25at\%Li 合金では Li の蒸気圧に比べて 1/103も小さくなり [17] , Li の活量をかなり下げること ができる . Flibeでは LiF の活量は低いが, $\mathrm{BeF}_{2}$ の蒸気 圧か問題になってくる[18].

\section{3 トリチウム回収装置}

水素溶解度を $1 \mathrm{~Pa}$ の水素圧で比較すると，Li は Li - Pb の約104倍, Flibe のさらに約104倍となる．したがって各 ブランケット材料からのトリチウム回収の考え方はかな り異なる．トリチウム回収装置で相互に関連するパラ メータとしてトリチウム漏洩率, トリチウムインベント リ，トリチウム回収率がある[19 20] .トリチウム回収の 観点に立てば, トリチウム溶解度を低くすること，系外
Table 3 Comparison of methods for tritium recovery from liquid blankets.

\begin{tabular}{|c|c|c|}
\hline 回収方法 & 操作の内容 & $\begin{array}{l}\text { 適用可能な } \\
\text { ブランケット材 }\end{array}$ \\
\hline $\begin{array}{l}\text { コールドト } \\
\text { ラップ }\end{array}$ & $\begin{array}{l}\text { 水素を加えた上, 液体を冷却し, 溶 } \\
\text { 解限度以上の LiT 水素化物固体を } \\
\text { フィルタによってろ過して除去 }\end{array}$ & $\mathrm{Li}, \mathrm{Li}-\mathrm{Pb}$ \\
\hline ホットトラップ & $\begin{array}{l}\text { トリチウム溶解度の大きい金属粒子 } \\
\text { 層(例えばイットリウム)に通し , } \\
\text { リチウムを吸蔵回収 }\end{array}$ & $\mathrm{Li}, \mathrm{Li}-\mathrm{Pb}$ \\
\hline 透過莣 & 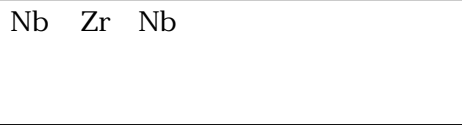 & $\begin{array}{l}\mathrm{Li}-\mathrm{Pb} \\
\text { F libe }\end{array}$ \\
\hline 溶融塩抽出 & $\begin{array}{l}\mathrm{LiF}-\mathrm{LiCl}-\mathrm{LiBr} \text { 溶融塩と混合して } \\
\text { 溶融塩側にトリチウムを液液抽出し } \\
\text { たあと, } \\
\text { ムを溶融塩を電解してトリチウ } \\
\text { ム収 }\end{array}$ & $\mathrm{Li}$ \\
\hline 気泡塔 & $\begin{array}{l}\mathrm{Li}-\mathrm{Pb}, \mathrm{Flibe} \text { 液滴と He ガスを向流 } \\
\text { 接触あるいは真空抽出し, 気相側に } \\
\text { トリチウムを回収 }\end{array}$ & $\begin{array}{l}\text { Li - Pb, } \\
\text { F libe }\end{array}$ \\
\hline スプレー塔 & $\begin{array}{l}\text { 塔内にFlibe を霧状に吹き出し, 溶 } \\
\text { 解しているトリチウムを真空排気し } \\
\text { て抽出 }\end{array}$ & Flibe \\
\hline
\end{tabular}

へのトリチウム漏洩率を低くするという観点に立てば， 平衡圧力を小さくすることが必要である．Li は前者に問 題があり，Flibe は後者に問題がある．T able 3 に想定さ れるトリチウム回収方法をあげた．Liでは，ホット卜 ラップ法と溶融塩抽出法が過去に1 at.ppm程度の水素同 位体の回収に成功している .コールドトラップは冷却に よる経済性に問題なければ現実的である.一方，Flibe のトリチウム溶解度はほぼ $1 \mathrm{~cm}^{3} / \mathrm{L}$ でありインベントリ には問題がないが, プールタイプあるいは冷却剂兼用タ イプのブランケットにかかわらず, 発生したトリチウム か環境にもれる量を $10 \mathrm{Ci} /$ day 以下にするのはかなり難 しく，適当な透過シールドあるいは二重管構造にする必 要がある.

(深田 智)

\section{3 熱工学とブランケット}

531 はじめに

核融合炉の炉心は炉心プラズマだが , 炉工学の立場で は熱を発生するブランケットが炉心であるとも言える . 熱の取り出し方式で核分裂炉か軽水炉，ガス炉などと分 類されるように, ブランケットからのエネルギー取り出 し方はシステム構築の要である . 過去に提案された多く のシステムは, 主として構造材料選択の制約から，冷却 方式と対を成すいくつかの候補概念に収斂しつつある が，ITER を目前にした現在も最終決定には至っていな 
い. 各冷却方式には弚れ光れ固有の熱工学課題が存在す るが, 身を蓋もない言い方をすれば, 熱伝達係数が一挙 に1桁も上がるような快刀乱麻の革新技術は乥うあるわ けではなく，冷却するだけならともかく，エクセルギー 損失を最小にして熱を取り出すという点で，できるもの はできるが無理なものは無理である. 材料がもたなけれ ば炉は成立しないから，熱工学は，材料側が絞り込んだ 各候補概念に対し, 熱エネルギー取り出しシステムとし ての成立の可否を，現実的なブレイクスルーの可能性を 含めて的確に指摘し，動力炉概念を絞り込む作業に貢献 しなければならない .

\section{2 ガス冷却に見るブランケットの基本問題} 候補のひとつである $\mathrm{SiC} / \mathrm{SiC}$ 複合材料を構造材とする 固体増殖, ヘリウムガス冷却の概念を例にして, ブラン ケットの基本問題を説明する．ただし，この語は筆者が 勝手に使っているものである .

核分裂炉では熱と核分裂生成物 (FP) が同じ燃料ぺ レット中で発生し, 燃料被覆が熱だけを外に出し FPを 中に留めるバリアの役目を果たす . FP は燃焼後バッチ 処理されるまでその位置に留まる.ペレットは稠密固体 で, 熱発生位置から被覆管までの熱移動は伝導であり， ペレットと被覆管の間に接触熱抵抗がある．

ブランケットでは熱とトリチウムが同じ増殖材中で発 生するが, トリチウムは処理系へ連続的に抽出されるの で,Fig.2の(B)のように，熱だけを冷却材に伝えるトリ チウムバリアと, トリチウムだけを除去系に透過させる 熱バリア (断熱壁) で増殖領域を構成して両者を別方向 へ誘導できれば, 動力サイクル側へのトリチウム漏洩と トリチウム除去系への熱漏洩をともに最小にできて理想 的である.しかし, 弚のようなバリアはともに目途が立 たず，現状の案では，図の(C)のように増殖領域を構成 する壁に“ある程度の”トリチウム透過障壁機能を期待
し，ペブル状の増殖材中にパージ用ヘリウムを通じてト リチウムを除去するようになっている . パージガスは， トリチウムを“たつぷり”吸わせて高分圧としたほうが 後の処理が楽であり，持ち出す余分な熱を最小にするた めにも，極く低速の流れとなる．

これを増殖域から冷却材への熱の流れで考えると，領 域内のパージ用へリウムはほとんど淀んだ状態であるか ら，熱の流れは，ヘリウムガスとペブル状固体増殖材か らなる充填層の熱伝導とわずかな輻射伝熱による. 球状 のペブル間の接触は基本的に点接触であり，ある程度の 充填率があっても熱伝導は結局パージガス層に律速され る、淀んだガスは基本的に断熱層であって伝熱層ではな い. 充填率を下げれば充填領域内の自然対流を幾分かは 活用できるが，乥れは増殖比を犠牲にする．層にバルク の応力を加えてペブル間の接触面積を増加させることが できるが，照射環境下で初期充填時の接触状態を維持す ることは保障の限りではない .

伝熱性能向上の基本は, 最も大きな伝熱抵抗を低減す ることであり，拡大伝熱面や乱流促進体などの手法を駆 使して冷却材と壁との間の伝熱を改善しても，増殖域内 の伝熱抵抗がほぼ全体を支配する，弚の改善には，増殖 材谷のもののを，例えば樹脂状のものなどに替えるより ないが, 光の場合には増殖材の成型シナリオからやり直 さなければならない .

分裂炉の燃料ペレットのような稠密固体の熱伝導で も，光の中心と表面の僅か 5 ミリほどの距離に 1,000 度 オーダーの温度差がある . 体積発熱密度に差があるとは 言え, ガス冷却方式は, 冷却材の出口温度自体を高くし て高効率のヘリウムガスタービンシステムを構筑するこ とを目指しており，以上の状況でブランケットの熱設計 は容易ではない 。

533 冷却材へのトリチウム漏洩

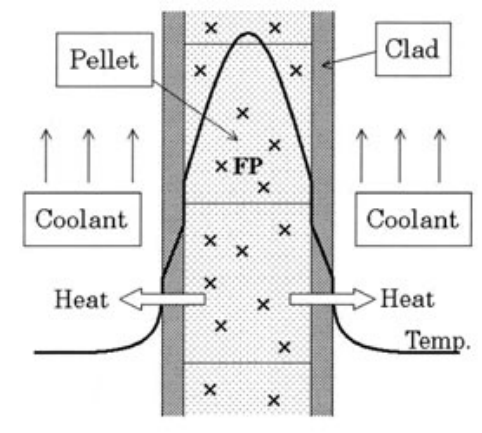

(A) fuel rod, fission reactor

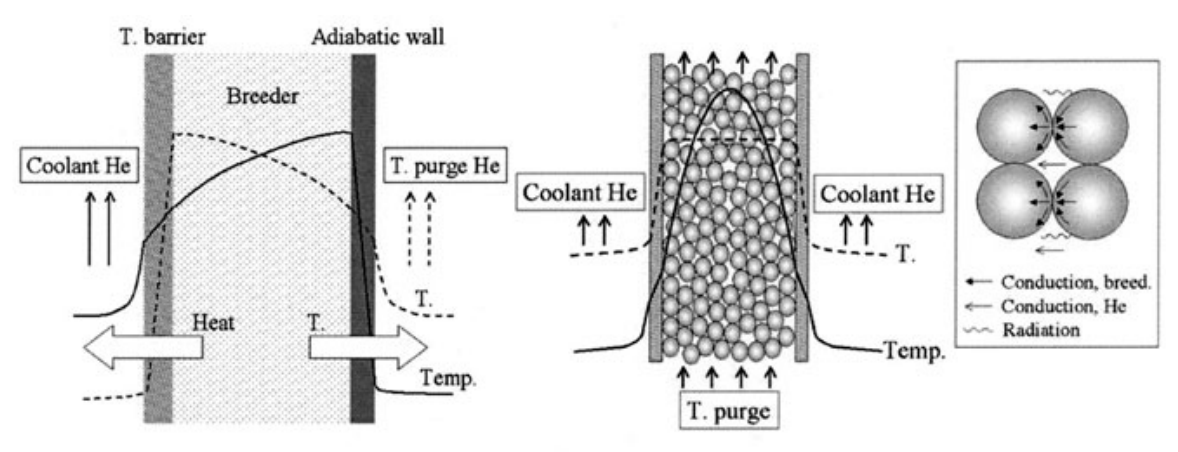

(B) Separated recovery of Heat and T. Fig. 2 Fundamental Roles of Blanket
(C) Pebble type breeder 
冷却材中へのトリチウム漏洩が避けられなければ，動 カサイクルの構筑も大きな問題を抱える. 产の場合は， 作動ガスの一部を連続的に抽気してトリチウムを除去し なければならないが, 除去にはある程度の分圧が必要 で , 結局動力サイクルの全体がトリチウム污染環境とな る.閉サイクルのヘリウムガスタービンでは, 同一軸に 取り付けられた圧縮機と膨張機の間でも軸受けでも， シールの問題が解決しておらず，外部に対するトリチウ ムバリアをどう設定するかが問題となる．いずれにせ よ，有効なトリチウムバリアの構築がシステム構成の鍵 を握り , バリアを諦めるなら初めから熱とトリチウムを 同じ流体で取り出すことを前提として，例えば増殖域を 流動層とする案などが浮上する .

5.4 自己冷却型増殖材

耐食性，耐放射化性能に優れたバナジウム合金の構造 材と液体金属の自己冷却型増殖材を用いる構想では，周 知のようにMHD 圧力損失による過大なポンプ動力を低 減するための電気絶縁皮膜の形成か鍵を握り，高温，照 射環境下での耐久性にある程度目途がつけられつつあ る.しかし，絶縁不良による予期せぬ MHD 効果が生じ れば，流れの乱流渦に顕著な非等方性が導入されて伝熱 性能が低下する懸念があり，伝熱性能に与える磁場の影 響がDNSを使って検討されている．

一方 , 大型へリカル炉の原型炉として構想されている FFHR では, 安全性とMHD 効果低減の観点から，もう ひとつの自己冷却型増殖材として溶融塩 (FLIBE) の使 用が検討されている.FLIBE は電気抵抗率が液体リシウ ムに比べて約 $1 \Omega \mathrm{cm}$ と格段に大きいのでMHD 抵抗から はほぼ解放され, トリチウム溶解度が極めて低い, 漏出 時の化学的反応性が低い, 蒸気圧が低く高温化でも常圧 運転が可能，などの特長ももつが，次点として，使用温 度範囲が下限側に融点で, 上限側に構造材のクリープ挙 動で光れ光れ制限され，現在は一次系の全体を450〜 550C内に収めるように構想されている. 動力サイクル としては二次系を閉サイクルヘリウムガスタービンとす る案を検討しているが，この温度で，しかも受熱温度範 囲が狭い閉サイクルガスタービンの効率確保はきわめて 難しい。これに対しては，多段圧縮，多段再熱，多段膨 張を利用して少しでもカルノーサイクルに近づけること で，約38\%の熱効率を達成できることを示した .この場 合は, 上述のトリチウムバリア , 軸シールの問題に加え て，作動ガスループが多くの熱交換器を含むので，圧損 を極限にまで抑制した高性能熱交換器の開発が鍵とな る。
同じ自己冷却・増殖材でも，液体金属と溶融塩の間に は伝熱機構に大きな違いがある．弚れは熱伝達の基本特 性を決めるプラントル数の違いである．液体LiとFLIBE

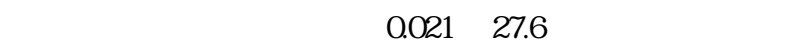
性に大きな差が生ずる．これに対しては，基本的な管内 流の対流熱伝達の整理式から再検討する試みが始まって いる．また，低いといっても電気伝導度はゼロでないか ら，液体金属の場合と同樣に，磁場による伝熱性能への 影響は十分に把握しておかなければならない .

\section{5 水冷却}

水は使い慣れた流体であり，既存の動力プラントの経 験も豊富であるから，低放射化フェライト鋼との組み合 わせは無難な選択である . 伝熱性能は十分に高く直接サ イクルを構築できるが, 過大な圧力の割りに高温化がで きない欠点がある. 既存の超々臨界圧火力では310気 圧，560足の蒸気条件で $42 \%$ 前後の熱効率が得られてい るが, ヘリウム脆化などの条件下でこのような圧力が維 持できるかは材料次第であり，水からのトリチウム回収 も問題である.

\section{6 ダイバータ}

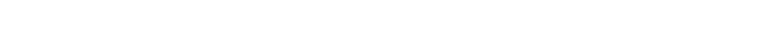
の除熱には確たる見通しが得られていない，定常時で約 10〜20 MW $/ \mathrm{m}^{2}$ とされるITERのダイバータ熱負荷に は, 捻りテープ入りスワール管内高速水流のサブクール 沸騰で対処することがほぼ確立されているが，動力炉で はダイバータ板の入熱量は核融合出力の約 2 割と見積も られ，この熱量が単なる冷却の対象としてほとんど捨て られるに等しい状態は, 設計上の大きなマイナスであ る . ガス冷却ではほほ絶望的であり，他の伝熱改善策を 考えるとともに, 入熱自体の低減策が必要である．

(清水昭比古)

\section{4 ブランケット核設計}

\subsection{1 はじめに}

ブランケット工学における核設計の役割は, トリチウ 么増殖比 (燃料の自己供給)，核発熱量 (エネルギ一变換 -増倍)，核的安全性能(遮蔽能, 誘導放射能, 核变換生 成物，崩壞熱等) について十分な精度で定量的に予測す ると同時に，これらを核融合炉システムの安全性と経済 性の観点から最適化を図ることにある、核設計の道具立 てには，いわゆる核データベースと中性子(および光子) の輸送・核反応過程をシミュレーションする計算コード が必要であるが，ここ10年来，ITER 設計等の国際的な 研究活動の後押しを受けて，この分野（核融合中性子工 
学分野)の着実な進展が得られている.ここでは,核デー タベースと計算手法の現状，これらの精度評価に必要不 可欠な積分ベンチマーク実験と炎の成果，および最近の 核設計研究の動向について概説する。

\subsection{2 核データベースと計算手法[21]}

核融合用核データベースの大きな成果としては， ITER への核設計利用を目的として開発・整備された評 価済み核データファイルFENDL $(-1,2)$ があげられる . これまで日，米，欧，露の4極て個別に作成されてきた 核データファイル (JENDL-FF, ENDF/B-VI，EFF， BROND) の中から核設計に必要な核種ごとにベストの ものを選定し統合するというもので, 1987年に作業が開 始されて，1998年に完了した .このFENDLは，後述の さまざまなベンチマーク積分実験の解析を通じて精度の 検証が行われ，現在のところ，核融合核設計計算用とし て世界的な参照核データベースの位置づけとなってい る.このほか, 核融合用核データの整備において, 非弾 性散乱で生じる 2 次中性子のエネルギーと角度分布を適 切に記述する二重微分断面積の重要性も認知された .

一方, 核設計に用いられる中性子・光子輸送計算コー ドについて，先進材料をべースとしたブランケット概念 の核的性能の当り計算，あるい最適構成の予備検討を行 j場合, 1 次元または 2 次元の決定論的手法 (Sn 法) の 計算コード(ANISN，ONEDANT，DOT，DORT など) か好んで用いられているが, 核融合炉の複雑な体系を模 擬するために，モンテカルロ法に基づく 3 次元計算 (MCNPなど)が主流となりつつある.モンテカルロ計算 は, 核データや体系近似に制約が少ないので, ベンチ マーク実験解析の結果を，核設計の精度 (マージン) 評 価に直接反映できる利点がある.大規模で複雑・詳細形 状の計算には, 計算効率 (計算時間) を改善するために， 複数のワークステーションを用いた並列分散処理が施さ れている[22] .

また，核融合核計算手法の今後の課題には，計算結果 の不確定性を直接算出することを目指して, 核データの 評価済み共分散データライブラリの作成・整備とモンテ カルロ計算をべースとした感度・不確定性解析コードの 開発か望まれている。

5.3 積分ベンチマーク実験と光の成果

核融合中性子工学における積分ベンチマーク実験は， 核データベースの評価精度のチェックや核設結果のマー ジン評価に極めて有効であり，従来より，この実験技術 の向上と良質なベンチマーク実験データの提供におい て, わが国の研究グループが果たした貢献は極めて大き

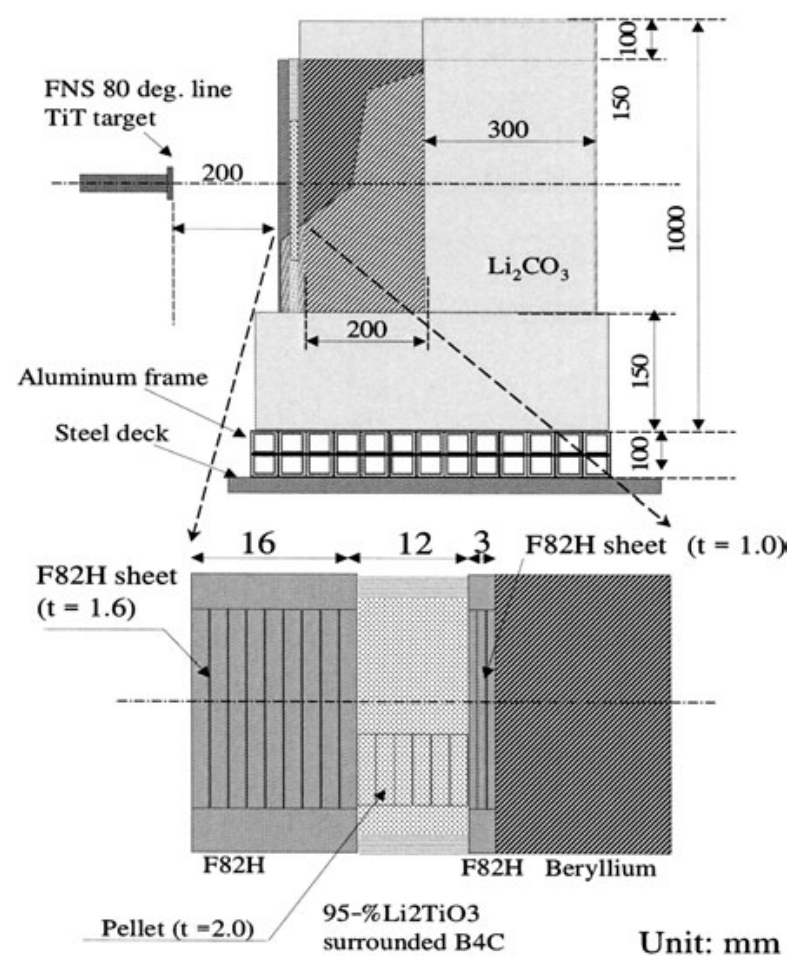

Fig. 3 Schematic view of experimental assembly for advanced blanket concept consisting of $95 \% \mathrm{CLi}_{2} \mathrm{TiO}_{3}, \mathrm{~F} 82 \mathrm{H}$ and $\mathrm{Be}$ layers.

い、ベンチマーク実験には, 核データ評価を主目的とし た単純て純粋な体系のクリーンベンチマークと実際の核 融合炉機器を模擬し, 設計関連の核的な応答の実験的検 証を目的とした設計指向（または工学実証）ベンチマー クと呼ばれる 2 種類があり，特に後者の実験では, 強力 DT 中性子源が欠かせない. わが国では，日本原子力研 究所FNSと大阪大学 OKTAVIAN という2つの強力 DT 中性子源施設を有した結果，世界に向けて先導的な研究 成果を出し続けている[23] . 設計指向ベンチマーク実験 の典型例として，原研 FNSで最近行われた先進ブラン ケット模擬の実験体系，即ち，95\%濃縮6 $\mathrm{Li}_{2} \mathrm{~T} \mathrm{iO}_{3}$ ，低放射 化フェライト鋼F $82 \mathrm{H}$ およびBeブロックからなる多層平 板体系をFig.3に示す.この体系に $14 \mathrm{MeV}$ 中性子を打ち 込み, ${ }^{6} \mathrm{Li}_{2} \mathrm{~T} \mathrm{iO}$ 層の卜リチウム生成率や $\mathrm{F} 82 \mathrm{H}$ 内の核反 応生成核種 $\left({ }^{56} \mathrm{Mn},{ }^{51} \mathrm{Cr},{ }^{187} \mathrm{~W}\right.$ など) の測定が行われ た．Fig.4にトリチウム生成率分布の実験と計算結果 (MCNP+JENDL - 3.2)の比較を示すが, 実験誤差の範囲 内で両者がよく一致していることがわかる[24] .

このような手順により，さまざまなな積分べンチマー ク実験解析を通じて現在までに得られているブランケッ 卜核設計にインパクトを与える主な知見は, 以下のとお 


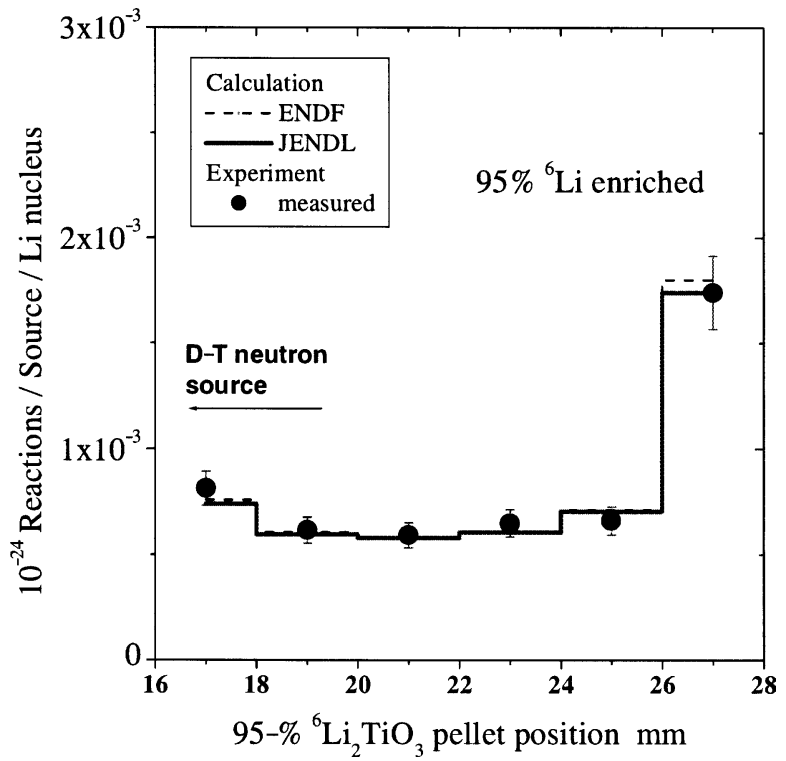

Fig. 4 Comparison between measured and calculated tritium production rates in $95 \%{ }^{6} \mathrm{Li}_{2} \mathrm{TiO}_{3}$ zone

りである[21] .

(1) トリチウム増殖能 : 予測精度〜 $5 \%(1 \sigma)$ 以内

(2) Be 中性子増倍特性 : 中性子増倍率の予測精度〜 $3 \%$ 以内であるが, 中性子スペクトル評価におい て低エネルギー側で過小評価の傾向 . 二次中性子 のエネルギー・角度分布の不確定性 (主に, 後方 散乱断面積) に改善の余地あり.

(3) 核発熱率: SS $316, \mathrm{Cu}$, グラファイト体系で は，10〜15\%の予測精度 .ただし，V，W，Zr では, $20 \%$ 以上の過大評価 .

(4) 遮蔽能 : 遮蔽およびストリーミングにおける中性 子束に関して, $1 \mathrm{~m}$ 深さで30\%以内の予測が可 能.

ブランケット積分ベンチマーク実験に関連した今後の 課題には，ITER 搭載用の試験ブランケットモジュール やDEMO 炉で想定される先進ブランケット設計を反映 した設計指向ベンチマーク実験があげられるほか，現在 でもあまり積分実験データが取得されていないA， $\mathrm{Si}, \mathrm{Ti}, \mathrm{Cr}, \mathrm{Zr}$, Nb およびSnのクリーン積分ベンチマー ク実験も必要と考えられる。

5.4 ブランケット核設計の動向

核データベースの高精度化や核設計手法の高度化に加 えて, 近年の安全性や経済性を追求した斬新なアイデア に基づく核融合炉システム設計研究においても，核設計 の重要度か増しつつある . 兴の典型例の1つとして, 米 国ARIESチームが実施した先進的なスフェリカルトカ
マク動力炉 A RIES-ST の設計研究例があげられる [25] . この研究では, 高出力を保ちながらコンパクトなシステ ムを構築する結果, センターポストのインボード遮蔽と 自己充足性を満たすブランケット核設計の最適化を図る 過程において，使用可能な構成材料や形状・配置等の取 捨選択がなされている．例えば，インボード遮蔽の強化 の必要性から，内部ブランケットの設置ができないた め, アウトボードブランケットのみで，1以上のトリチ ウム増殖比を確保することになる．弚の結果，ブラン ケット材として固体増殖材は適用困難であり， $\mathrm{LiPb} /$ 低 放射化フェライト鋼/SiC/Heのような構成にたどり着く が , この選定はインボードの遮蔽材に高性能な遮蔽に適 したW と水の利用を拒むような結論が得られている.こ のように先進的な核融合炉システムの設計研究では，従 来にも増して核設計が本体の基本構造を決定する立場に なっており, 大変興味深い . わが国でも，低アスペクト 比卜カマク動力炉 (VECTOR) の概念設計において, 超 伝導コイルに対する遮蔽能とトリチウム増殖能という核 設計パラメータのトレードオフから，種々の先進ブラン ケット材料の選定や構成パターンを検討した研究報告が なされている[26] .

以上のように , これからのブランケット核設計研究に おいて, 核データベースや核計算手法に基づく不確定性 (設計マージン)の改善は, 斬新な核融合システム概念の 創出に大きなインパクトをもたらすと言えよう．

(井口哲夫)

\section{参考文献}

[ 1 ] Y. Kaw amura and M. Nishikawa, J. Nucl. Mater . 218, 57 (1995).

[ 2 ] Y.Kaw amura, M. Nishikaw et al., J. Nucl. Mater. 230, 287 (1996).

[ 3 ] A . Baba, M. Nishikaw a and T. Eguchi, J. Nucl. Mater. 250, 29 (1997).

[ 4 ] M. Nishikaw a and A. Baba, J. Nucl. Mater. 257, 162 (1998).

[ 5 ] M.Nishikaw a et al., J. Nucl. Sci. T echnol. 38,944(2001).

[ 6 ] N.Nakashio and M.Nishikaw a,F usion T echnol.33,287 (1998).

[ 7 ] M. Nishikawa, S. Beloglazov et al., Proc. 9th Int. WS on Ceramic Breeder Interaction (2000) p.129.

[ 8 ] T. Kaw agoe, M. Nishikaw a, A . Baba and S. Beloglazov, J. Nucl. Mater. 297, 27 (2001).

[ 9 ] N. Nakashima, S. Beloglazov, K. Hashimoto and M. Nishikaw a, F usion Sci. T echnol. 41, 1044 (2002).

[10] K. Hashimoto, M.Nishikaw a, N. Nakashima, S. Belogla- 
zov and M.Enoeda, F usion Eng. Des. 61-62, 375 (2002).

[11] S.Beloglazov,M .Nishikaw aand T .T anifuji,F usion Sci. T echnol. 41, 1049 (2002).

[12] 溶融塩熱技術研究会 : 溶融塩熱技術の基礎(アグネ技 術センター，1993).

[13] H. Moriy ama, A .Sagara et al., F us. Eng.Des. 39-40,627 (1998).

[14] H. Nishimura, T .T erai et al., J. Nucl. Mater. 299, 1355 (2002).

[15] S. Fukada, R.A . A nderl et al., Fus. Eng. Des. 61-62, 783 (2002).

[16] D A . Petti, R A . A nderl et al., F us. Sci. T echnol. 41, 807 (2002).

[17] R. . A nderl et al., J. Nucl. Mater. 307-311, 739 (2002).

[18] D.R. Olander et al., F us. Sci. T echnol. 41, 141 (2002).
[19] S. Fukada, A . Sagara et al., F us. Sci. T echnol. 41,1054 (2002).

[20] 深田 智, 西川正史 : 富山大学水素同位体機能研究 センター研究報告 14,1(1994).

[21] U.F ischer, P.Batistoni, Y . Ikeda and M Z.Y oussef, F usion. Eng. Des. 51-52 663 (2000).

[22] G.V ella, P.Chiovaro et al., F usion. Eng. Des. 61-62, 439 (2002).

[23] I. Murata, T . Nishio et al., F usion. Eng. Des. 51-52, 821 (2000).

[24] K. Ochiai, A . Klix, et al., J. Nucl. Sci. T echnol. Suppl.2, 1147 (2002).

[25] Laila A . EI-Guebaly, F us. Eng. Des. 65, 263 (2003).

[26] 山内通則, 佐藤 聡 他 : 日本原子力学会「2003年春 の年会」 E14 (2003). 